\title{
Educating the Concepts of Retention Factor of a Company with the Case of Employee Engagement Level Increase
}

\section{Educar los conceptos del factor de retención de una empresa con el caso del aumento del nivel de compromiso de los empleados}

\author{
Natalia A. Tsareva \\ Vladivostok State University of Economics and Service, Russia \\ ORCID: https://orcid.org/0000-0002-5448-9222 \\ Vera A. Boldyhanova \\ Vladivostok State University of Economics and Service, Russia \\ ORCID: https://orcid.org/0000-0002-4633-6605
}

Recibido 12-12-19 Revisado 13-02-20 Aprobado 20-04-20 En línea 27-04-20

Correspondencia

Email: natsareva@mail.ru
Citar como:

Tsareva, N. A., Boldyhanova, V. A. (2020). Employee engagement level increase as its retention factor in company. Propósitos y Representaciones, $8(3)$. http://dx.doi.org/10.20511/pyr2020.v8n3.515

(C) Universidad San Ignacio de Loyola, Vicerrectorado de Investigación, 2020.

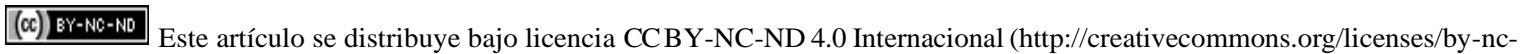
$\mathrm{nd} / 4.0 /)$. 


\section{Summary}

The current socio-economic situation creates similar conditions and rules for companies in various industries around the world.in this vein, the study and educate the retention factors of the company are of a great importance. The task of staff productivity increase and the overall effectiveness of its activities is relevant. The most important role in addressing the issue of employee productivity and performance increasing, as well as his retention is played by employee engagement. The researchers studying engagement at work recognize that this phenomenon is multifaceted and define it as an employee's physical, cognitive and emotional state, causing excessive performance of his functional duties. Involvement is interconnected with the motivational potential of work, therefore, the conditions for the engagement development are the following ones: work significance and diversity, the comparison of work with its result. The authors of the article conducted the study of engagement at work in the enterprises of fishing and fish processing industries. We determined the problems that impede the growth of staff engagement. The authors of the article implemented the program of corrective actions aimed to improve the factors affecting the engagement at work and retention of staff. We determined the interdependence of involvement level and the coefficient of staff turnover, as well as the return of employees to some holding.

Keywords: Assessment of Engagement at Work; Engagement at Work; Job Satisfactio; Employee Loyalty; Staff Retention; Labor Motivation; Staff Turnover.

\section{Resumen}

La situación socioeconómica actual crea condiciones y reglas similares para las empresas de diversas industrias en todo el mundo. En este sentido, el estudio y la educación de los factores de retención de la empresa son de gran importancia. La tarea de aumentar la productividad del personal y la efectividad general de sus actividades es relevante. El papel más importante para abordar el problema del aumento de la productividad y el rendimiento de los empleados, así como su retención, lo desempeña el compromiso de los empleados. Los investigadores que estudian el compromiso en el trabajo reconocen que este fenómeno es multifacético y lo definen como el estado físico, cognitivo y emocional de un empleado, lo que provoca un desempeño excesivo de sus deberes funcionales. La participación está interconectada con el potencial motivador del trabajo, por lo tanto, las condiciones para el desarrollo del compromiso son las siguientes: importancia y diversidad del trabajo, la comparación del trabajo con su resultado. Los autores del artículo realizaron el estudio de la participación en el trabajo en las empresas de las industrias pesqueras y de procesamiento de pescado. Determinamos los problemas que impiden el crecimiento de la participación del personal. Los autores del artículo implementaron el programa de acciones correctivas destinadas a mejorar los factores que afectan el compromiso en el trabajo y la retención del personal. Determinamos la interdependencia del nivel de participación y el coeficiente de rotación del personal, así como el retorno de los empleados a alguna explotación.

Palabras clave: Evaluación del compromiso en el trabajo; Compromiso en el trabajo, satisfacción laboral; Lealtad de los empleados; Retención del personal; Motivación laboral; Rotación del personal.

\section{Introduction}

In modern economic environment, company executives are aware of the importance of not just the availability of qualified human resources, but also of key employee special value, who differ not only in the highest possible efficiency, but also in their high level of engagement at work. In recent years, more and more attention of Russian experts is attracted by the process of company 
employee engagement development. One of the most important factors of an enterprise efficiency engagement at work is to increase employee engagement in the activities of his enterprise. Many successful companies strive to create the most comfortable, safe working conditions, to unite people into an emotionally positive team that is aimed to achieve results. An involved employee feels necessary for an organization and feels that his contribution to the work is assessed properly by management. Engagement at work is considered the highest level of attitude towards the performance of functional duties when a person works as best as possible for the good of a company. Engagement reflects the level of organization-employee relationship. This problem and the search for the ways of its solution are more than urgent for Russian organizations. HR-services currently have the task of valuable personnel attraction and retaining using various tools.

\section{Methods}

The term "personal engagement" was introduced by V. Kahn in 1990, describing the interaction of an employee and an organization as a unique motivational concept: the use of employee selfawareness from the point of view of physical, cognitive and emotional components for functional duty performance (Kahn, 1990). Involvement characterizes the state of an employee, in which he is fully absorbed by the values of an employer and shares them (Thomas, 1990). People who are aware of their importance tend to feel worthy, useful, valuable and able to carry out their responsibilities more effectively (Kan, 1990). They describe several levels in studies that determine the attitude of employees to a company:

- Satisfaction is an "emotional state" (Locke, 1976), which focuses on one's own expectations, experience and is characterized by “ self-serving behavior" (Kjell et al., 2015);

- Loyalty as a socio-psychological attitude of an employee to an organization, who is characterized by the acceptance of its goals and values, the desire to work in it (Shaufeli et al., 2002; Demushina, 2015);

- Engagement is characterized by satisfaction with the functional component of their work, interest in their own professional growth, employees accept and support the organizational culture of a company.

From the very beginning, involvement was viewed as a positive opposition to burnout associated with the work of a state characterized by mental exhaustion (Maslach et al., 2001; Tsareva et al., 2019). Inactivity in the workplace, like burnout, is characterized by low inspiration and discontent (Lowedow et al., 2009), while labor activity is characterized by high inspiration and pleasure. Participation in work can be determined using the JD-R model "Requirements and Operational Resources" (Bakker, Demerouti, 2014). The JD-R model provides a clear overview of the relationship between requirements, resources, psychological states and work results. The combination of high work requirements and high resources leads to high levels of motivation, and involvement in work (Tuckey et al., 2012), which in its turn leads to high levels of productivity (Bakker, Bal, 2010; Van Wingerden et al., 2015). Employees can increase their own work engagement and productivity by their work requirement and resource optimization via job crafting (Tsareva et al., 2018). A high level of labor resources (e.g., feedback, remuneration, autonomy, support) leads to the reduction of work requirements, the achievement of work goals and facilitation of training and advanced training (Demuriti et al., 2001; Arnaut, 2017). The conditions for staff engagement development are the following ones: personnel strategy, organizational and psychological climate, satisfaction with working conditions, self-realization, motivation (Yakimova, Tsareva, 2017). In order to involve employees, it is important to have the sense of belonging to a common cause, the satisfaction with new opportunities for intellectual development (Nedoluzhko et al., 2016). Employee engagement in an enterprise activity, being a special type of employee's attitude to work, is characterized by a set of motives for effective work and socio-economic indicator improvement of an enterprise activity (Terentyeva, 2017). The level 
of an employee engagement is determined by the strength of internal motivation - labor motives that are formed under the influence of internal factors, the system of incentives provided by an organization (Tsareva et al., 2016). Intrinsic motivation is encouraged by both the working context and individual differences that contribute to a sense of competence, autonomy and relativity (Gagne, Deci, 2005), and it is argued that this affects productivity through the internalization of the goals faced by an organization (Baard et al, 2004). The motives of work, which form the engagement of staff, are influenced by many internal and external factors: the value system, the incentive system, the level of corporate culture, the socio-psychological atmosphere, the relations with the manager and colleagues, the conditions of life in an organization, and many other factors (Yakimova et al., 2018; Yakimova et al., 2019). The knowledge of the main factors that have the greatest influence on the engagement of the majority of enterprise personnel is of practical value.

\section{Results and Discussion}

The conduct of research on engagement in Russian companies is becoming an increasingly common practice every year. Most managers consider it necessary to maintain feedback with employees by conducting annual surveys (Tsareva et al., 2017). Top managers track the ways of existing process and recently implemented project evaluation (Karimova, 2017). To identify the level of engagement by most researchers, they use Utrecht scale of engagement in work (UWES) (Schaufeli, Bakker, 2003). In order to study the engagement of staff, the Human Capital Development Agency (HCDA) developed its questionnaire, which includes four blocks with 22 factors: engagement, commitment, loyalty, and satisfaction.

The study was conducted in the fishing and fish processing holding, which includes a fish canning plant, 3 floating bases, a repair and shipbuilding plant, a tin canned food industry, 12 fishing vessels, and an administrative warehouse complex. The main method of the study was chosen HCDA questionnaire, adapted for employees and including 30 questions, combined into 5 blocks: satisfaction with working conditions; work satisfaction; satisfaction with the interaction; interest in the company; satisfaction with opportunities and development prospects. The company began to study this issue in 2017 in order to determine the employee engagement index and identify the areas to increase the attractiveness of the holding as an employer and employee retainer. 1537 people were interviewed (46\% of workers). The survey was conducted in all divisions, the proportion of respondents amounted to $65 \%$ of the crew. The total level of employee engagement was $70.4 \%$ in 2017, which is in the range of average values for the companies around the world. The lowest rates were identified by the following factors: wage system, interactions, work processes. According to the results of the study, focus groups were organized in each division and they prepared the plan of corrective actions. According to the factor "Labor Remuneration System", they developed the brochure, an employee was appointed to explain this calculation; trainings were conducted for the employees who work on piecework wages. The regulation was adopted for the factor "Vertical communications", - all appeals should be considered as a matter of priority and an answer should be provided. They worked out the rules for meetings with the head of the workers to discuss production indicators, plans, etc. Corrective work was carried out on the factors "Resources" (equipment was updated), "Experience and knowledge" (training was resumed through the mentoring system), etc.

When they conducted a re-survey at the beginning of 2019, the question was added readiness to the next sailing/ to stay and the new scale "Importance". The changes allowed to focus on those who fell into the zone "Important - not satisfied". 1818 people took part in the survey, which made up 53\% of all working employees and $68 \%$ of the crew. Thus, the increase was found in all indicators throughout the holding. The overall level of employee engagement was 73.5. Table 1 shows the staff engagement ratio. 
Table 1.

The staff engagement rate by personnel fields and categories in 2019

\begin{tabular}{|c|c|c|c|c|c|c|c|c|c|c|}
\hline \multirow[t]{2}{*}{ Factor } & \multicolumn{2}{|c|}{$\begin{array}{l}\text { Administrativ } \\
\text { e and } \\
\text { warehouse } \\
\text { complex }\end{array}$} & \multicolumn{2}{|c|}{ Fish cannery } & \multicolumn{2}{|c|}{ Shipyard } & \multicolumn{2}{|c|}{$\begin{array}{l}\text { Canning } \\
\text { production }\end{array}$} & \multicolumn{2}{|c|}{ Fleet } \\
\hline & $\begin{array}{l}\text { Wor } \\
\text { kers }\end{array}$ & $\begin{array}{r}\text { Manag } \\
\text { ement }\end{array}$ & $\begin{array}{l}\text { Wor } \\
\text { kers }\end{array}$ & $\begin{array}{r}\text { Manag } \\
\text { ement }\end{array}$ & $\begin{array}{l}\text { Wor } \\
\text { kers }\end{array}$ & $\begin{array}{r}\text { Manag } \\
\text { ement }\end{array}$ & $\begin{array}{l}\text { Wor } \\
\text { kers }\end{array}$ & $\begin{array}{l}\text { Manag } \\
\text { ement }\end{array}$ & $\begin{array}{l}\text { Wor } \\
\text { kers }\end{array}$ & $\begin{array}{r}\text { Manag } \\
\text { ement }\end{array}$ \\
\hline $\begin{array}{c}\text { Emplo } \\
\text { yee } \\
\text { engage } \\
\text { ment } \\
\text { index, } \\
\%\end{array}$ & 84,3 & 81,5 & 68,0 & 72,0 & 76,1 & 78,3 & 78,0 & 80,6 & 65,9 & 77,8 \\
\hline $\begin{array}{l}\text { Satisfa } \\
\text { ction } \\
\text { with } \\
\text { basic } \\
\text { workin }\end{array}$ & 83,5 & 80,6 & 66,1 & 68,7 & 72,2 & 75,3 & 70,8 & 76,2 & 65,3 & 74,0 \\
\hline $\begin{array}{c}\mathrm{g} \\
\text { conditi } \\
\text { ons, } \%\end{array}$ & & & & & & & & & & \\
\hline $\begin{array}{c}\text { Satisfa } \\
\text { ction } \\
\text { with } \\
\text { work } \\
\text { process } \\
\text { es, \% }\end{array}$ & 86,3 & 87,4 & 71,2 & 75,2 & 81,3 & 84,2 & 80,5 & 83,5 & 69,8 & 84,5 \\
\hline $\begin{array}{l}\text { Satisfa } \\
\text { ction } \\
\text { with } \\
\text { interact } \\
\text { ion, \% }\end{array}$ & 84,2 & 78,1 & 66,0 & 68,4 & 78,3 & 78,8 & 75,6 & 75,7 & 64,6 & 75,6 \\
\hline $\begin{array}{l}\text { Interest } \\
\text { in } \\
\text { compa } \\
\text { ny, \% }\end{array}$ & 87,2 & 84,1 & 66,9 & 72,4 & 77,1 & 80,5 & 81,8 & 85,0 & 56,1 & 71,1 \\
\hline $\begin{array}{c}\text { Satisfa } \\
\text { ction } \\
\text { with } \\
\text { opport } \\
\text { unities } \\
\text { and } \\
\text { develo } \\
\text { pment } \\
\text { prospe } \\
\text { cts, \% }\end{array}$ & 80,2 & 77,2 & 69,8 & 75,2 & 71,7 & 72,8 & 81,4 & 82,8 & 73,7 & 83,9 \\
\hline
\end{tabular}

The overall result of all remedial work was a general decrease of the holding staff turnover rate by $5 \%$. The corrective action program is aimed at of working and living condition quality improvement on ships. The turnover rate of personnel for individual vessels decreased by $30 \%$. 
The result of employee engagement level study was the division of the overall results into 4 groups: "Develop", "Save", "Strengthen", "Weigh" (Figure 1).

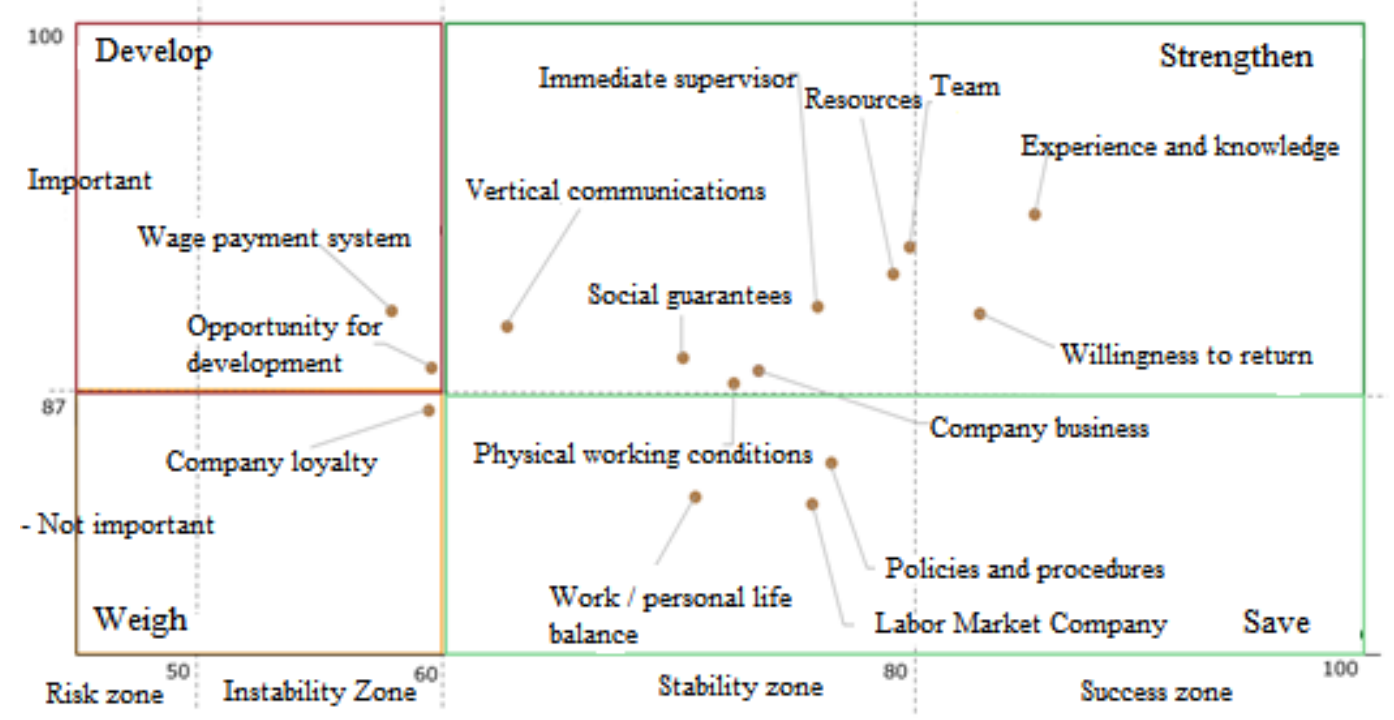

Figure 1. General indicator of satisfaction and importance for the holding

The indicator "Opportunities for Development" hit the critical zone. One of the main reasons for this low rate is the lack of rotation system in a company. There is "School of Masters" only at the fish cannery, after which employees can upgrade their qualifications and acquire the position of master. The factor "Labor remuneration system" grew by $6.5 \%$. After corrective actions, the staff turnover rate dropped to $36.8 \%$. Every fourth employee of the holding works on floating bases or fishing vessels. The return to a fishing vessel allows you to talk about both employee loyalty and his involvement. According to the survey of 2019, the crew asked the question about the previous place of work $-60.3 \%$ got on ships after the work in this holding in 2017, while their share was only $24.2 \%$ in 2016 . The overall result of the measures taken to increase the level of staff engagement was the reduction of the staff turnover rate throughout the holding and the return of employees to work at the fishing and fish processing vessels of the holding.

\section{Conclusion}

In the current conditions of economic relations at an enterprise, success-oriented enterprises must control the level of employee engagement and evaluate the factors that reduce it. The study examined the main theoretical and methodological foundations of engagement. In the course of work, they conducted the review of methods to study the engagement of personnel in the work of an organization. Questionnaires are formed on the basis of practical developments of specific companies, carrying out applied research of staff engagement in various foreign and Russian organizations. The research results show that the program of corrective actions in personnel management contributes to the engagement of employees, can improve productivity, through engagement in work, job satisfaction and intrinsic motivation. Another consequence of engagement level increase is the retention of the company staff - the decrease of staff turnover rate and the return of the crew to the fishing company vessels. An organization can improve the level of staff engagement by improving working conditions, employees' awareness of wage calculation procedure, vertical communication development that provide feedback. Managers using this practice to increase the factors can increase the level of employee engagement and, thus, reduce the staff turnover rate, and guarantee the return of employees to ships for the crew. 
Thus, the conducted studies have led to the conclusion that the development of the company personnel engagement occurs through the provision of labor and production resource interaction to achieve the goals of an enterprise - improvement of efficiency in general and qualified employee retaining.

\section{References}

Arnaut, M. N., \& Tsareva, N. A. (2017). Economic and adaptation mechanism in human resource management. Azimuth of scientific research: economics and administration, 6, 3(20), 3538.

Baard, P., Deci, E., \& Ryan, R. (2004). Intrinsic need satisfaction: A motivational basis of performance and well-being in two work settings. Journal of Applied Social Psychology, 34, 2045-2068.

Bakker, A. B., \& Bal, P. M. (2010). Weekly work engagement and performance: a study among starting teachers. J. Occup. Organ. Psychol, 83, 189-206.

Bakker, A. B., \& Demerouti, E. (2014). Job demands-resources theory. in Wellbeing: A Complete Reference Guide, eds C. Cooper and P. Chen, 37-64.

Demerouti, E., Bakker, A.B., De Jonge, J., Janssen, P. P. M., \& Schaufeli, W. B. (2001). Burnout and engagement at work as a function of demands and control. Scand $J$ Work Environ Health, 27, 279-286.

Demushina, O. N. (2015). Factors influencing employee loyality in the commercial organization. Azimuth of scientific research: Pedagogy and Psychology, 1(10), 65-70.

Gagne', M., \& Deci, E. (2005). Self-determination theory and work motivation. Journal of Organizational Behavior, 26, 331-362.

Kahn, W. A. (1990). Psychological Conditions of Personal Engagement and Disengagement at Work. Academy of Management Journal, 33, 692-724.

Kahn, W. A. (1992). To be fully there: Psychological presence at work. Human Relations, 45, 321-349.

Karimova, O. S. (2017). The experience of studying employee loyalty in a commercial organization. Azimuth of scientific research: Pedagogy and Psychology, 6, 3(20), 298300.

Kjell, O., Daukantaite, D., Hefferon, K., \& Silkstrom, S. (2015). The Harmony in Life Scale Complements the Satisfaction with Life Scale: Expanding the Conceptualization of the Cognitive Component of Subjective Well-Being. Social Indicators Research. Published online Feb, 18.

Krasova, E. V., \& Xiu, Y. X. (2016). Modern Trends in the Formation of Human Resources as a Factor in Sustainable Development of China's Economy. Economic and Social ChangesFacts Trends Forecast, 45(3), 205-220.

Locke, E. A. (1976). The nature and causes of job satisfaction. In M. D.Dunnette (Ed.), Handbook of industrial and organizational psychology. Chicago: Rand McNally, 1297-1343.

Loukidou, L., Loan-Clarke, J., \& Daniels, K. (2009). Boredom in the workplace: More than monotonous tasks. International Journal of Management Reviews, 11, 381-405.

Maslach, C., Schaufeli, W. B., \& Leiter, M. P. (2001). Job burnout. Annual Review of Psychology, $52,397-422$.

Nedoluzhko, O. V., Varkulevich, T. V., \& Baturina, O. A. (2016). Evolution of individual's intellect as basis for forming intellectual capital of organization. Journal of Advanced Research in Law and Economics, 7(2), pp. 332-340.

Nedoluzhko, O. V., \& Oslopova, M. V. (2019). Intellectual capital of organization in categorizing a universal scheme of interaction between its elements. Amazonia Investiga, 8(19), pp. 12-20.

Schaufeli, W., \& Bakker, A. (2003). The Utrecht Work Engagement Scale (UWES): Test Manual. Utrecht: Utrecht University. 58 p.

Schaufeli, W., Salanova, M., González-Romá, V., \& Bakker, A. (2002). The Measurement of 
Engagement and Burnout: A Two Sample Confirmatory Factor Analytic Approach. Journal of Happiness Studies, 3, 71-92.

Terentyeva, T. V., \& Korneyko, O. V. (2017). New approaches to interpretation of entrepreneurship in context of modern development of the Russian economy. Espacios, $38(62), 33$.

Thomson, K. M. (1990). The Employee Revolution: Corporate Internal Marketing. Pitman publishing. London, 66-80.

Tsareva, N. A., Yakimova, Z. V., \& Vlasenko, A. A. (2019). Job crafting role, staff involvement and work stress. Dilemas Contemporáneos: Educación, Política y Valores, 6.

Tsareva, N. A., Erokhin, A. K., \& Vlasenko, A. A. (2018). Development of effective interaction at work: job crafting and employee's emotional competence. The Turkish Online Journal of Design, Art and Communication. March. Special Edition, 583-590.

Tsareva, N. A., Vlasenko, A. A., \& Kololokova, L. A. (2017). Actual questions of human resources management. The Turkish Online Journal of Design, Art and Communication. April Special Edition, 1208-1218.

Tsareva, N. A., Vlasenko, A. A., \& Ivanuyga, O. I. (2016). The concept of labour motivation of the modern Russian scientists. The Turkish online journal of design art and communication, 2571-2585.

Tuckey, M. R., Bakker, A. B., \& Dollard, M. F. (2012). Empowering leaders optimize working conditions for engagement: a multilevel study. J. Occup. Health Psychol, 17, 15-27.

Van Wingerden, J., Bakker, A. B., \& Derks, D. (2015). The impact of personal resources and job crafting interventions on work engagement and performance. Hum. Resour. Manage. 56, $51-67$.

Yakimova, Z. V. \& Tsareva, N. A. (2017). Mechanisms of development of valuable human resource management. Azimuth of scientific research: economics and administration, 6 , 4(21), 294-298.

Yakimova, Z. V., Tsareva, N. A., \& Zhuk, A. E. (2019). Modeling the value proposition of the employer in the context the type of organizational culture. Azimuth of scientific research: economics and administration, 6, 1(21), 294-298.

Yakimova, Z. V., \& Pushkina, A. S. (2018). Dynamics of the level of employee engagement depending on seniority in the organization. Azimuth of scientific research: economics and administration, 7, 1(22), 283-286. 